\title{
MICROBIAL TRANSFORMATIONS OF TRU AND MIXED WASTES: ACTINIDE SPECIATION AND WASTE VOLUME REDUCTION
}

\author{
(FINAL REPORT)
}

\author{
A. J. Francis (PI) and C. J. Dodge
}

November 2006

\author{
Environmental Sciences Department \\ Environmental Research \& Technology Division \\ Brookhaven National Laboratory \\ P.O. Box 5000 \\ Upton, NY 11973-5000 \\ www.bnl.gov
}

Notice: This manuscript has been authored by employees of Brookhaven Science Associates, LLC under Contract No. DE-AC0298CH10886 with the U.S. Department of Energy. The publisher by accepting the manuscript for publication acknowledges that the United States Government retains a non-exclusive, paid-up, irrevocable, world-wide license to publish or reproduce the published form of this manuscript, or allow others to do so, for United States Government purposes. 


\section{DISCLAIMER}

This report was prepared as an account of work sponsored by an agency of the United States Government. Neither the United States Government nor any agency thereof, nor any of their employees, nor any of their contractors, subcontractors, or their employees, makes any warranty, express or implied, or assumes any legal liability or responsibility for the accuracy, completeness, or any third party's use or the results of such use of any information, apparatus, product, or process disclosed, or represents that its use would not infringe privately owned rights. Reference herein to any specific commercial product, process, or service by trade name, trademark, manufacturer, or otherwise, does not necessarily constitute or imply its endorsement, recommendation, or favoring by the United States Government or any agency thereof or its contractors or subcontractors. The views and opinions of authors expressed herein do not necessarily state or reflect those of the United States Government or any agency thereof. 


\title{
MICROBIAL TRANSFORMATIONS OF TRU AND MIXED WASTES: ACTINIDE SPECIATION AND WASTE VOLUME REDUCTION
}

\author{
A.J. Francis (PI) and C.J. Dodge \\ Environmental Sciences Department, Brookhaven National Laboratory, Upton NY 11973
}

\section{RESEARCH OBJECTIVES}

The overall goals of this research project are to determine the mechanism of microbial dissolution and stabilization of actinides in Department of Energy's (DOE) TRU wastes, contaminated sludges, soils, and sediments. This includes (i) investigations on the fundamental aspects of microbially catalyzed radionuclide and metal transformations (oxidation/reduction reactions, dissolution, precipitation, chelation); (ii) understanding of the microbiological processes that control speciation and alter the chemical forms of complex inorganic/organic contaminant mixtures; and (iii) development of new and improved microbially catalyzed processes resulting in immobilization of metals and radionuclides in the waste with concomitant waste volume reduction.

\section{RESEARCH PROGRESS AND IMPLICATIONS}

This is a final report which summarizes work after 3 years of a 3 year project.

\section{REDUCTIVE DISSOLUTION OF PLUTONIUM}

Anaerobic microbial dissolution of Pu. We investigated the biotransformation of ${ }^{242} \mathrm{Pu}$ -

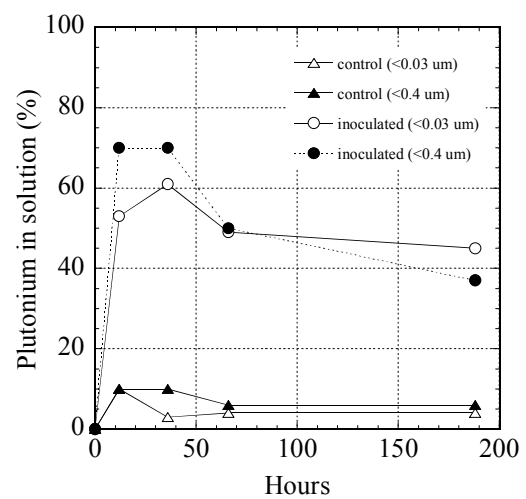

Fig. 1. Dissolution of polymeric Pu species by the activity of Clostridium sp.

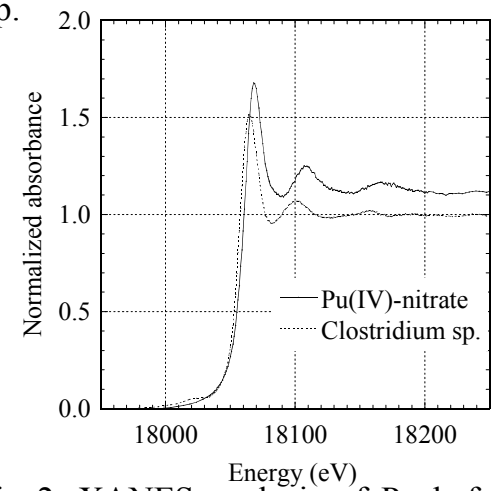

Fig 2. XANES analysis of Pu before (i-) and following (---) anaerobic microbial activity. nitrate by the anaerobic bacterium Clostridium sp. Adding $1 \times 10^{-7} \mathrm{M}^{242} \mathrm{Pu}(\mathrm{IV})$-nitrate had no effect upon its growth and metabolism of glucose. Ninety percent of the added $\mathrm{Pu}$ in uninoculated growth medium (control) was removed by $0.4 \mu \mathrm{m}$ filtration, and most likely existed as $\mathrm{Pu}(\mathrm{OH})_{4}$ at $\mathrm{pH} 6.2$ due to hydrolysis and polymerization reactions. The growth of Clostridium sp. lowered the Eh to $-180 \mathrm{mV}$ and the $\mathrm{pH}$ from 6.2 to 2.8 , concomitant with the production of the organic acids, acetic and butyric (12 and $17 \mathrm{mM}$, respectively), and carbon dioxide $(225 \mu \mathrm{mol})$. After $14 \mathrm{~h}$ of growth, $70 \%$ of the $\mathrm{Pu}$ passed through a $0.4 \mu \mathrm{m}$ filter and $55 \%$ through a $0.03 \mu \mathrm{m}$ filter. This suggests that a soluble form of $\mathrm{Pu}$ was present and not a polymeric form.

Pu Speciation. Reduction of $\mathrm{Pu}(\mathrm{IV})$ to $\mathrm{Pu}(\mathrm{III})$. Solvent extraction of the growth medium using thenoyltrifluoroacetone (TTA) at $\mathrm{pH} 0$ and $\mathrm{pH} 4$ confirmed a decrease in polymeric form of $\mathrm{Pu}$ and an increase in the soluble fraction suggesting the presence of $\mathrm{Pu}^{3+}$ (data not shown). The Eh of the medium was highly reducing $(-180 \mathrm{eV})$. X-ray absorption near edge spectroscopy (XANES) analysis of the culture at the $\mathrm{Pu} \mathrm{L}_{\text {III }}$ edge $(18.057 \mathrm{keV})$ confirmed the oxidation state as $\mathrm{Pu}^{3+}$ (Figure 2). Solvent extraction of each treatment showed a 
dramatic increase in the amount of $\mathrm{Pu}$ found in the fraction indicative of the soluble $\mathrm{Pu}$ species. The organic fraction at $\mathrm{pH} 4$, indicative of $+3,+4$, and $+6 \mathrm{Pu}$ oxidation states, increased from 74 $\mathrm{dpm} / \mathrm{ml}$ in the uninoculated growth medium to $575 \mathrm{dpm} / \mathrm{ml}$ in the presence of unfiltered spent medium. The organic fraction at $\mathrm{pH} 0$, indicative of $\mathrm{Pu}^{4+}$ only, increased less dramatically from $46 \mathrm{dpm} / \mathrm{ml}$ in the uninoculated growth medium to $224 \mathrm{dpm} / \mathrm{ml}$ in the unfiltered spent medium. These results confirm that $\mathrm{Pu}$ is solubilized by Clostridium sp. following its reduction to $\mathrm{Pu}^{3+}$.

Mechanisms of Pu Dissolution. Pu biotransformation by direct or indirect action of Clostridium sp. was determined. Indirect mechanisms due to metabolite production, as well as, Eh and $\mathrm{pH}$ of the medium was determined in the absence of bacterial cells using (i) uninoculated pre-reduced, autoclaved growth medium, (ii) pre-reduced synthetic spent medium containing

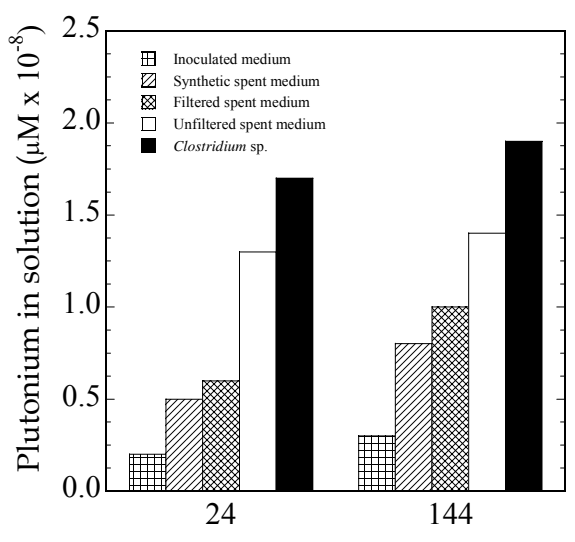

Figure 3. Effect of microbial extracellular metabolic products on solutilization of $\mathrm{Pu}(\mathrm{IV})$. organic acids in the proportions found at logarithmic growth phase, (iii) unfiltered cell-free spent medium obtained from a 24-h old culture, and (iv) filtered cell-free spent medium $(0.45 \mu \mathrm{m})$. Direct action was determined in the presence of growing bacterial cells. The extent of $\mathrm{Pu}$ dissolution by various treatments is shown in Figure 3. At 144-h, the uninoculated growth medium showed $15 \%$ of the $\mathrm{Pu}$ remained in solution following filtration through a $0.45 \mu \mathrm{m}$ filter. In the synthetic spent medium $41 \%$ of the $\mathrm{Pu}$ was solubilized, in the filtered spent medium $33 \%$ of the $\mathrm{Pu}$ was in soluble form, and the unfiltered spent medium had $54 \%$ of the $\mathrm{Pu}$ in soluble form. This compares with $74 \%$ of the $\mathrm{Pu}$ passing through the filter in the presence of bacteria

\section{BIODEGRADATION OF ORGANIC LIGANDS IN TRU WASTES}

Isosaccharinic acid. The presence of organic ligands in radioactive wastes is a major concern because of their potential for increasing the transport of radionuclides from disposal

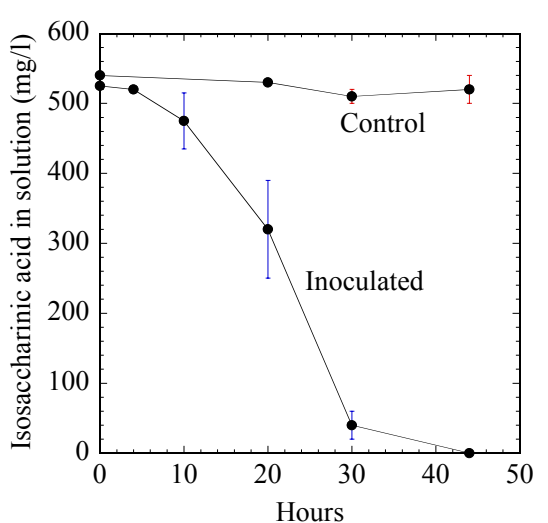

Fig 4. Biodegradation of ISA by an aerobic soil bacterial isolate. sites. Biotransformation of radionuclides complexed with organic ligands should precipitate the radionuclides and retard their migration. Isosaccharinic acid (ISA) is a degradation product of cellulose when exposed to radiation at high $\mathrm{pH}$. ISA is also known to form strong complexes with actinides (An) and may enhance their mobility from waste sites. Biodegradation of An-ISA complexes should retard the mobility of actinides. We investigated the biodegradation of ISA by an aerobic bacterium (grampositive rod) isolated by enrichment culture technique. Degradation of ISA by the bacterial isolate is shown in Figure 4. Currently, we are investigating the biotransformation of the metal- and radionuclide-ISA complexes under both aerobic and anaerobic conditions.

Pu-citrate. Structural determination of Pu:citric acid complex. The molecular association of $\mathrm{Pu}(\mathrm{IV})$ with citric acid was determined so that a structure-function relationship 
could be obtained. The XANES spectra for $\mathrm{Pu}(\mathrm{IV})$-nitrate and Pu-citrate complexes are presented in Figure 5A. The first derivative of the absorption-edge energy for the Pu-citrate complex is at $18060 \mathrm{eV}$. This is identical to that for the $\mathrm{Pu}(\mathrm{IV})$-nitrate standard, thereby confirming the tetravalent oxidation state of the Pu-citrate complex. Figure 5B and 5C shows the $\mathrm{k}^{3}$-weighted (2.5-12.5 $\AA^{-1}$ ) raw EXAFS spectrum and the Fourier transform for the Pu-citrate complex. The inner-sphere coordination number for $\mathrm{Pu}$ is 10.0 and includes three distinct $\mathrm{O}$ shells. There are 5.0 $\pm 1.2 \mathrm{O}$ 's at $2.26 \pm 0.02 \AA, 3.5 \mathrm{O}$ 's at $2.41 \pm 0.02 \AA$, and $1.5 \pm 0.8 \mathrm{O}$ atoms at $2.69 \pm 0.02 \AA$. The atoms closest to the $\mathrm{Pu}$ at $2.26 \AA$ are due to the presence of water and other uncoordinated oxygens. The $3.5 \mathrm{O}$ atoms at $2.41 \AA$ are coordinated to the $\mathrm{Pu}$ through the carboxylate oxygens of two citric acid molecules. The $\mathrm{O}$ atoms at $2.69 \AA$ are most probably due to coordination with the $\alpha$-hydroxyl oxygens of citric acid. No $\mathrm{Pu}-\mathrm{Pu}$ interaction typical for $\mathrm{Pu}(\mathrm{IV})$-hydroxo complexes is observed. Based upon this analysis the best configuration for the molecule consists of a mononuclear biligand complex.
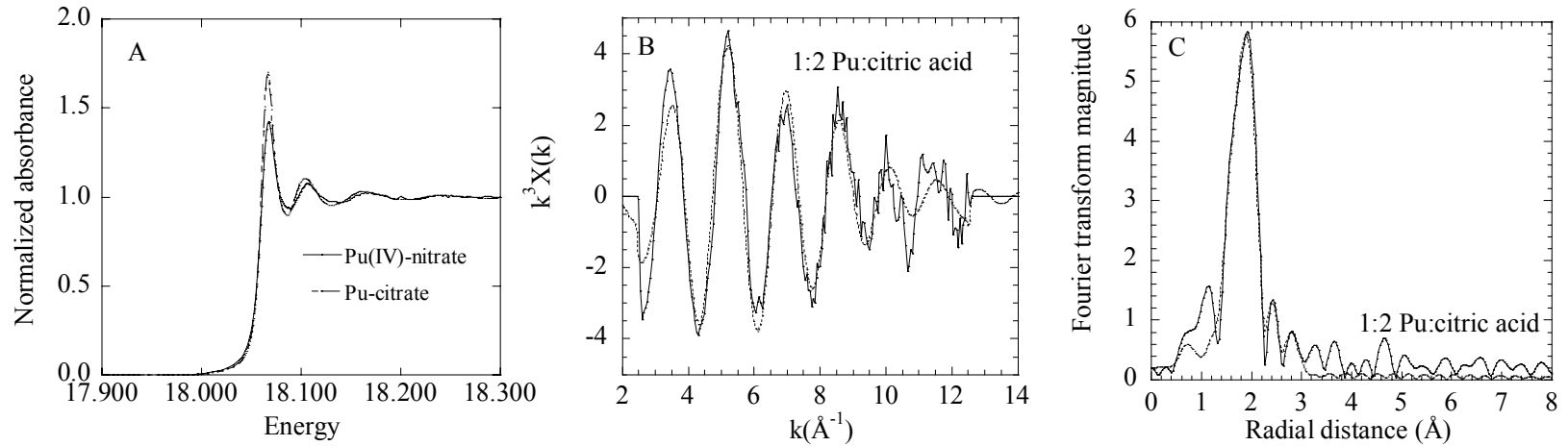

Figure 5. XANES spectrum for $\mathrm{Pu}(\mathrm{IV})$-nitrate and $\mathrm{Pu}$-citrate complex (A); and $\mathrm{k}^{3}$-weighted data (B) and Fouriertransformed EXAFS spectrum (C) for Pu:citric acid complex. Experimental data (-);fitted data (---).

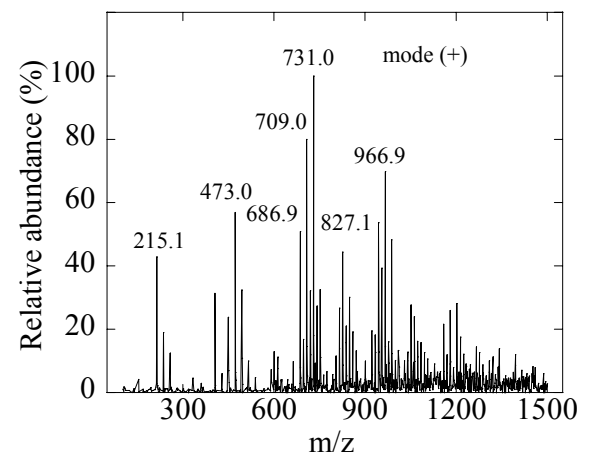

Figure 6. Electrospray ionization (ESI-MS) spectra produced by $\mathrm{Pu}$-citrate complex.
Figure 6 shows the ESI-MS spectra for singly charged positive ions peaks of $1.6 \times 10^{-4} \mathrm{M}$ Pu-citrate complex. The dominant peaks are due to the formation of a monomeric Pu-citrate complex at $\mathrm{m} / \mathrm{z} \quad 473.0$ $\left[\text { Pucit }\left(\mathrm{H}_{2} \mathrm{O}\right) \mathrm{Na}\right]^{+}$(Figure 7A) and biligand complex formation is indicated by the presence of peaks at $\mathrm{m} / \mathrm{z} 686.9$ $\left[\mathrm{Pu}\left(\mathrm{H}_{2} \mathrm{cit}\right)_{2} \mathrm{NO}_{3}\right]^{+}, \mathrm{m} / \mathrm{z} 709.0\left[\mathrm{Pu}(\mathrm{Hcit})\left(\mathrm{H}_{2} \mathrm{cit}\right) \mathrm{NaNO}_{3}\right]^{+}$, and $\mathrm{m} / \mathrm{z} 731.0\left[\mathrm{Pu}(\mathrm{Hcit})_{2} \mathrm{Na}_{2} \mathrm{NO}_{3}\right]^{+}$(Figure 3B). The presence of a dimeric $\mathrm{Pu}$ complex is noted at $\mathrm{m} / \mathrm{z} 966.9$ $\left[\mathrm{Pu}_{2}(\mathrm{Hcit})(\mathrm{cit})\left(\mathrm{NO}_{3}\right)_{2}\right]^{+}$(Figure $7 \mathrm{C}$ ). The $\mathrm{m} / \mathrm{z}$ values are considered accurate to within 1 or 2 amu's. Based upon the

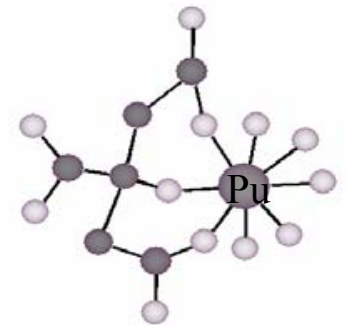

A

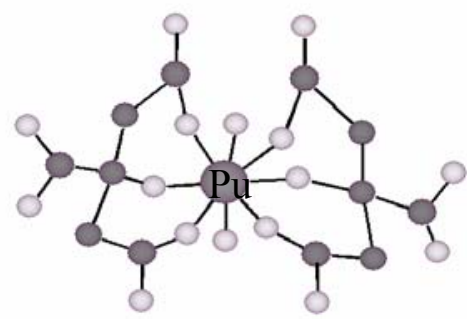

B

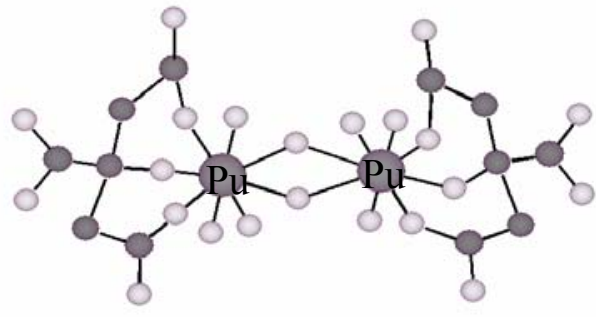

$\mathrm{C}$

Figure 7. Proposed structures at $\mathrm{pH} 6$ for the monoligand 1:1 Pu:citric acid complex (A); biligand 1:2 Pu:citric-acid complex $\left[\mathrm{PuO}(\mathrm{cit})_{2}\right]^{4-}(\mathrm{B})$; and dimeric 2:2 Pu:citric acid complex $(\mathrm{C})$. The open circles represent oxygen and the filled circles represent carbon atoms. 
speciation calculations, X-ray absorption spectra, and LC-MS data, we propose a biligand $\left[\mathrm{Pu}\left(\mathrm{cit}_{2}\right)\right]$ complex structure, similar to that suggested by Metivier and Guillaumont (Figure 7B).

Biodegradation of citric acid and Pu-citrate complexes. Figure $8 \mathrm{~A}$ depicts the rate and extent of citrate degradation in samples containing $10^{-6} \mathrm{M}$ and $10^{-8} \mathrm{M} \mathrm{Pu}$ present as $\mathrm{Pu}$-citrate complexes at an ionic strength of $0.18 \mathrm{M}$. Citric acid $\left(10^{-4} \mathrm{M}\right)$ in the absence of $\mathrm{Pu}$ was metabolized completely at a rate of $4.9 \mu \mathrm{M} / \mathrm{h}$. With $10^{-6}$ and $10^{-8} \mathrm{M}$ Pu present as the Pu-citrate
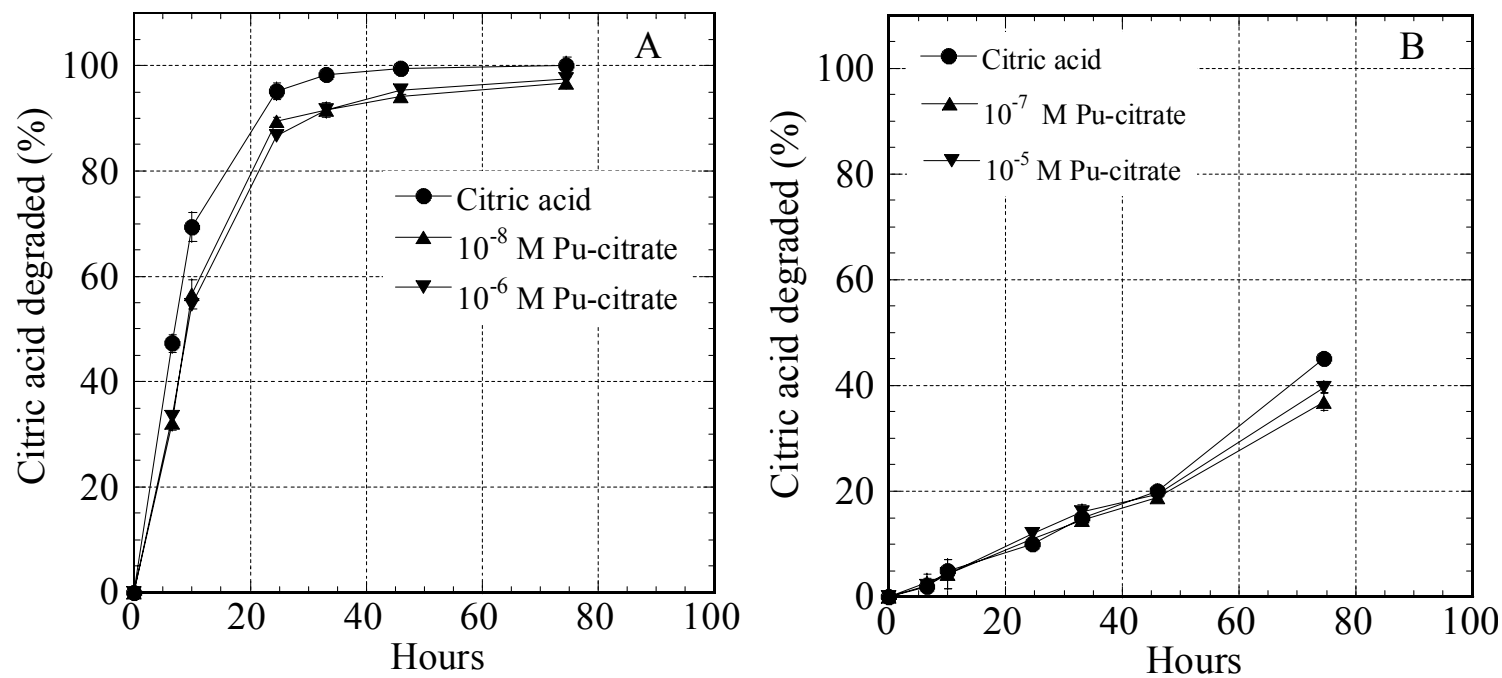

Figure 8. Effect of adding ${ }^{242} \mathrm{Pu}$ on citrate metabolism at an ionic strength of $0.18 \mathrm{M}(\mathrm{A})$ and ionic strength $0.9 \mathrm{M}(\mathrm{B})$.

complex we observed a slight decline on the rate and extent of citrate degradation in comparison to the sample lacking $\mathrm{Pu}$. In both samples, citrate was degraded $>96 \%$, and at the rate of 4.0 $\mu \mathrm{M} / \mathrm{h}$ and $3.8 \mu \mathrm{M} / \mathrm{h}$, respectively. Increasing the ionic strength of the medium affected citrate metabolism. In high ionic-strength medium $(0.9 \mathrm{M})$ containing $10^{-7}$ and $10^{-5} \mathrm{M} \mathrm{Pu}$ present as $\mathrm{Pu}-$ citrate complex, the rate and extent of citrate degradation was much lower at $0.8 \mu \mathrm{M} / \mathrm{h}$ in the $10^{-7}$ and $10^{-5} \mathrm{M} \mathrm{Pu}$ treatments with an overall degradation of $37 \%$ and $35 \%$, respectively (Figure $8 \mathrm{~B}$ ). Without $\mathrm{Pu}$, there was a slight increase in degradation to $45 \%$ of the total citric acid Table 1. Speciation of $\mathrm{Pu}$ following 70-h incubation with P. fluorescens. concentration.

\begin{tabular}{|c|c|c|c|c|}
\hline \multirow[b]{2}{*}{ Analysis } & \multirow[b]{2}{*}{ Oxidation state } & \multicolumn{2}{|c|}{$\mathrm{Pu}$} & \multirow{3}{*}{$\begin{array}{l}\text { Speciation of plutonium } \\
\text { before and after aerobic } \\
\text { bacterial }\end{array}$} \\
\hline & & Total activity (dpm) & Total extracted $(\%)$ & \\
\hline$\underline{10^{-6}} \underline{\mathrm{MPu}}$ & & & & \\
\hline $\mathrm{TTA}_{\text {org }}(\mathrm{pH} 4)$ & $+3,+4,+6$ & $64.5 \pm 3.5$ & $30 \pm 5$ & Thenoyltrifluoroacetone \\
\hline $\mathrm{TTA}_{\mathrm{aq}}(\mathrm{pH} 4)$ & +5 , polymer & $154 \pm 17$ & $70 \pm 11$ & (TTA) was used to \\
\hline $\mathrm{TTA}_{\text {org }}(\mathrm{pH} 0)$ & +4 & $66 \pm 12$ & $24 \pm 5$ & determine the \\
\hline $\mathrm{TTA}_{\mathrm{aq}}(\mathrm{pH} 0)$ & $+3,+5,+6$, polymer & $206 \pm 10$ & $76 \pm 4$ & state of $\mathrm{Pu}$ in the unfiltered \\
\hline$\underline{10^{-5}} \underline{\mathrm{MPu}}$ & & & & $\begin{array}{l}\text { samples following } 70 \text { hours } \\
\text { of bacterial activity. }\end{array}$ \\
\hline $\mathrm{TTA}_{\text {org }}(\mathrm{pH} 4)$ & $+3,+4,+6$ & $501 \pm 44$ & $19 \pm 9$ & Extraction of the low ionic \\
\hline $\mathrm{TTA}_{\mathrm{aq}}(\mathrm{pH} 4)$ & +5 , polymer & $2110 \pm 220$ & $81 \pm 10$ & strength sample containing \\
\hline $\mathrm{TTA}_{\text {org }}(\mathrm{pH} 0)$ & +4 & $443 \pm 18$ & $20 \pm 4$ & $10^{-6} \mathrm{M} \mathrm{Pu}$ at $\mathrm{pH} 4$. showed \\
\hline $\mathrm{TTA}_{\mathrm{aq}}(\mathrm{pH}$ 0) & $+3,+5,+6$, polymer & $1740 \pm 180$ & $80 \pm 10$ & $70 \%$ of the $\mathrm{Pu}$ was present \\
\hline
\end{tabular}


as polymeric form with the remainder most probably as $\mathrm{Pu}^{4+}$ (Table 1). Although the TTA extraction also suggests the presence of $\mathrm{PuO}_{2}{ }^{+}$, it is more likely that the tetravalent form is present as indicated by the XANES data. Extraction of the medium at $\mathrm{pH} 0$ reveals that the predominant form of $\mathrm{Pu}(76 \%)$ is the polymer species.

Extracting the high ionic strength $10^{-5} \mathrm{M} \mathrm{Pu}$ into the aqueous phase at $\mathrm{pH} 4$ indicated that $\mathrm{Pu}$ was predominantly polymeric, similar to the $10^{-6} \mathrm{M} \mathrm{Pu}$ sample. The speciation at $\mathrm{pH} 0$ is similar to the results obtained at $\mathrm{pH} 4$, with the polymeric species comprising $80 \%$ of the total $\mathrm{Pu}$ in the sample. The predominance of polymeric form of $\mathrm{Pu}$ in both treatments is most probably due to the biodegradation of citric acid which was almost completely metabolized at $10^{-6} \mathrm{M} \mathrm{Pu}$ and $40 \%$ biodegraded in the $10^{-5} \mathrm{M} \mathrm{Pu}$ treatments. In addition, the higher concentration of $\mathrm{Pu}$ in the $10^{-5} \mathrm{M}$ sample may enhance polymer formation..

Tetravalent plutonium forms a 1:1 Pu:citric acid $\left(\mathrm{K}=10^{19}\right)$ complex and a 1:2 Pu:citric acid complex $\left(\mathrm{K}=10^{34}\right)$. In the presence of excess citric acid, their solubility and $\mathrm{Pu}(\mathrm{IV})$ oxidation state are stable. At $\mathrm{pH}$ 6.5, we identified a monomeric [Pucit] species, two forms of biligand $\left[\mathrm{Pucit}_{2}\right]$ species, and a dimeric $\left[\mathrm{Pu}_{2} \mathrm{Cit}_{2}\right]$ species of tetravalent plutonium with citric acid. Speciation calculations and ESI-MS show that the biligand complex is the predominant form. In addition, analysis of the complex over 100-h demonstrated that citric acid inhibits polymer formation. Although the $\mathrm{Pu}(\mathrm{IV})$-citrate complex is stable in the absence of microbial activity, adding bacteria to the 1:100 and 1:10000 $\mathrm{Pu}(\mathrm{IV})$-citrate complexes resulted in the retention of $\mathrm{Pu}$ species at $20-43 \%$ by the $0.4 \mu \mathrm{m}$ (biomass associated)-filter, and $27-57 \%$ by the $0.03 \mu \mathrm{m}$ (colloid fraction)-filter. Plutonium behavior during microfiltration of the 1:10 and 1:1000 treatments, where citrate metabolism was moderate, suggests that biosorption of the Pu-citrate complex alone is not responsible for removing Pu from solution since it remained in soluble form (>93\%).

\section{BACTERIAL DISSOLUTION OF ACTINIDES IN NTS SOIL}

Characterization of Pu-contaminated Nevada Test Site (NTS) soil. Plutonium

Table 2. Isotopic activity in NTS soil.

\begin{tabular}{ccc}
\hline Isotope & \multicolumn{2}{c}{ NTS Soil } \\
& $(\mathrm{nCi} / \mathrm{g})$ & $(\mu \mathrm{g} / \mathrm{g})$ \\
\hline $\mathrm{U} 233 / 234$ & $<0.18$ & $<6.1 \times 10^{-2}$ \\
$\mathrm{U} 235 / 236$ & $<0.15$ & $<3.6 \times 10^{1}$ \\
$\mathrm{U} 238$ & $<0.14$ & $<4.2 \times 10^{2}$ \\
Am 241 & $3.8 \pm 0.7$ & $1.1 \times 10^{-3}$ \\
$\mathrm{Pu} 238$ & $0.44 \pm 0.02$ & $2.6 \times 10^{-5}$ \\
$\mathrm{Pu} 239 / 240$ & $69.2 \pm 6.5$ & $1.1 \times 10^{-1}$ \\
\hline
\end{tabular}
contaminated soil (HP-11) was obtained from Area 11 soil of the Double Track test shot area at the NTS and had a gross activity of $50 \mathrm{nCi} / \mathrm{g}$. The individual alpha components of the total activity were determined and are given in Table 2. The beta-emitter Pu-241 has also been detected but was not quantified.

Mineral content and association of Pu in NTS soil. Minerals present in the soil were determined using $\mu-X-$ ray diffraction measurement on beamline $\mathrm{X} 7 \mathrm{~A}$ at the National Synchrotron Light Source (NSLS). The predominant minerals consisted of various forms of iron oxides and aluminosilicates. The uranium was present in the soil as hexavalent form associated as the minerals schoepite $\left(\mathrm{UO}_{3} \cdot 2 \mathrm{H}_{2} \mathrm{O}\right)$ and liebigite $\left(\mathrm{Ca}_{2} \mathrm{UO}_{2}\left(\mathrm{CO}_{3}\right)_{3} \cdot 11 \mathrm{H}_{2} \mathrm{O}\right)$. Association of $\mathrm{Pu}$ in the soils was attempted on beamline X27A. However, the Pu signal was below the detection limit of the methods $(<1 \mu \mathrm{g})$.

Synchrotron scanning transmission X-ray microscopy (STXM) analysis was performed by Drs. D. Shuh, P. Nico and T. Tyliszczak at the Advanced Light Source (ALS), Berkeley, CA. The "as received" soil sample was analyzed on the Molecular Environmental Sciences beamline 
ALS-MES 11.02. The image of the soil presented in Figure 9A is a $4 \mu \mathrm{m} \times 4 \mu \mathrm{m}$ spot size

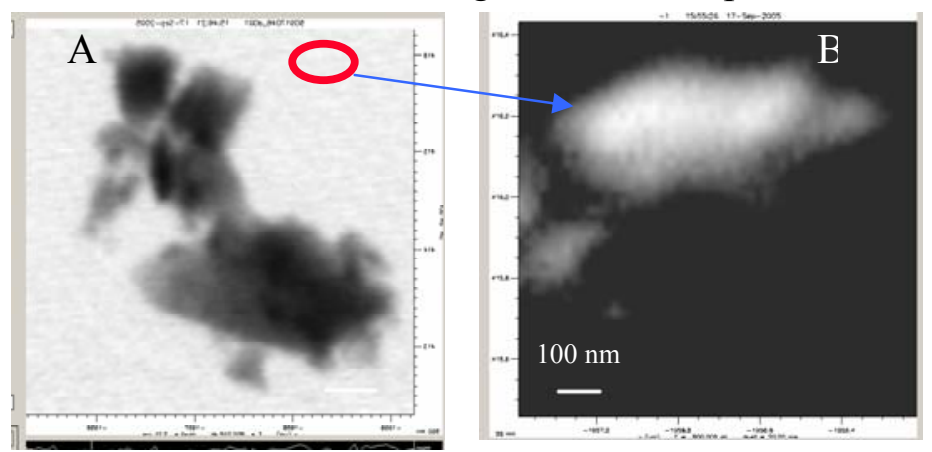

Figure 9. Synchrotron scanning transmission X-ray microscopy for NTS soil showing particles (A) and Pu-containing region (B).

obtained at an energy of $800 \mathrm{eV}$. Figure 9B shows the image of $\mathrm{Pu}$ obtained using a resolution of $<100 \mathrm{~nm}$ ). The $\mathrm{Pu}$ distribution is localized to a small area of the sample (approx. $500 \mathrm{~nm}$ ) and suggests it is present as polymeric form.

Effect of bacterial activity on mobilization of $\mathrm{Pu}, \mathrm{Am}$, and $\mathrm{U}$ in NTS soil. The effect of bacterial
is presented in Figure 10. Under both activity on the mobilization of radionuclides in NTS soil is presented in Figure 10. Under both aerobic and anaerobic conditions the degradation of glucose occurred with decrease in $\mathrm{pH}$ to 5.2
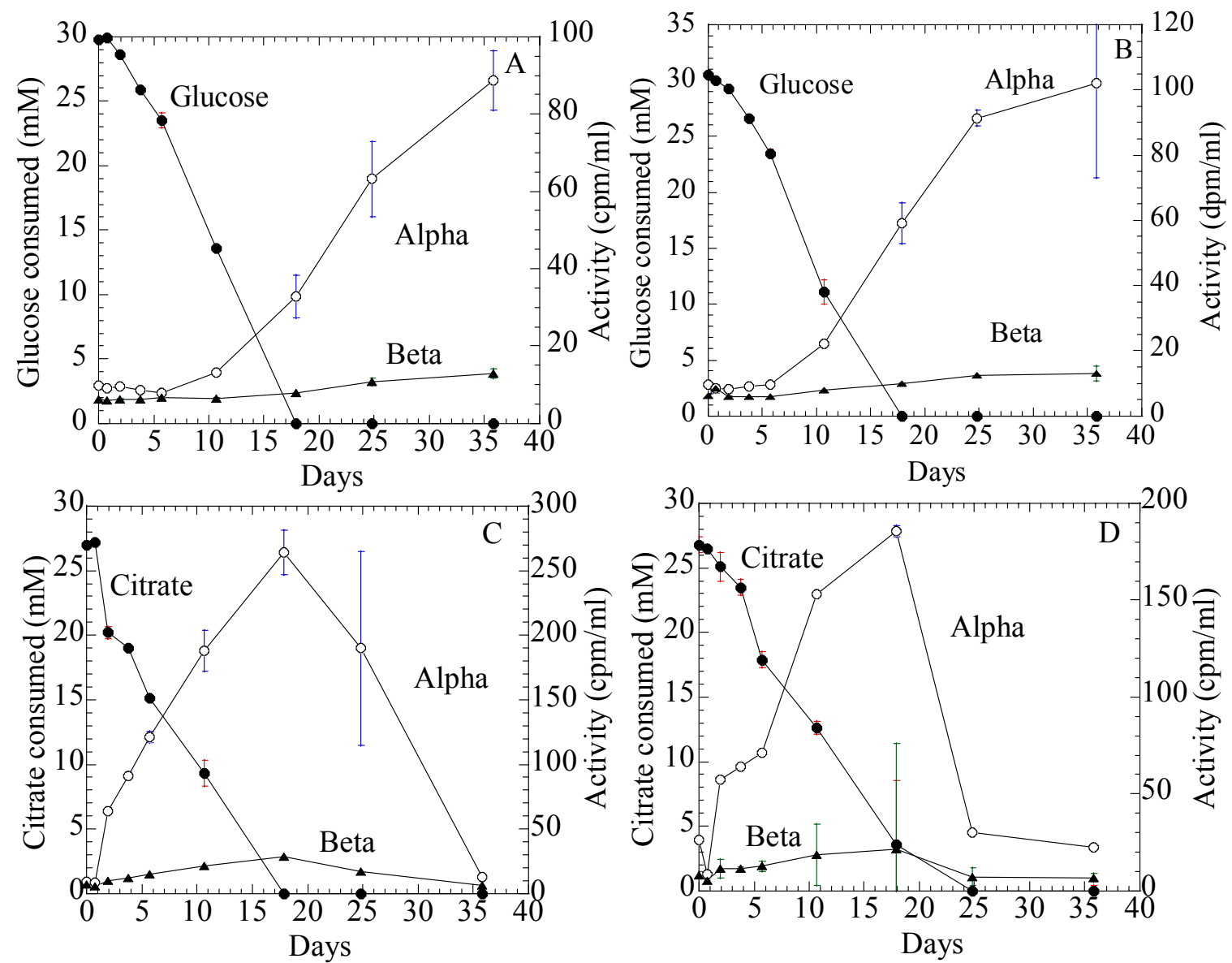

Figure 10. Effect of carbon utilization by indigenous bacteria on the mobilization of actinides.

for the aerobic sample and 4.83 for the anaerobic sample and an increase in actinide activity in solution. However, the appearance of the actinide in solution was concomitant with decrease in $\mathrm{pH}$ and not related to consumption of glucose (Fig. 10A and 10B). This indicates that the 
predominant mechanism for alpha and beta release into solution is due to the slightly acidic $\mathrm{pH}$ of the spent medium. In addition, the alkaline nature of the soil suggests that mobilization may be due to dissolution of carbonate species present in the soil.

During the aerobic and anaerobic metabolism of citric acid both alpha and beta activity increase in solution up to $17-d$. However with increase in time the activity begins to decrease (Figure 10C and 10D). This loss of activity in solution coincides with the complete utilization of citric acid by the bacteria. There is only slight decrease in $\mathrm{pH}$ during the experiment to 7.7 in the presence of aerobic bacteria and 7.4 in the presence of anaerobic bacteria. This observation suggests that citric acid forms a soluble complex with the actinide and that its removal due to bacterial metabolism releases the actinide, resulting in its precipitation. These results also suggest that the type of carbon source will have different effect on microbial mobilization of actinides.

\section{INFORMATION ACCESS}

1. Yoshida, T., T. Ozaki, T. Ohnuki, and A. J. Francis. 2004. Interactions of trivalent and tetravalent heavy metal-siderophore complexes with Pseudomonas fluorescens, Radiochim. Acta 92: 749-753.

2. Ozaki, T., J.B. Gillow, T. Kimura, T. Ohnuki, Z. Yoshida, A.J. Francis. 2004. Adsorption behavior of $\mathrm{Eu}(\mathrm{III})$ and $\mathrm{Cm}(\mathrm{III})$ on the cell surfaces of microorganisms, Radiochim. Acta. 92: 741-748.

3. Yoshida, T., T. Ozaki, T. Ohnuki, A.J. Francis. 2004. Adsorption of rare earth elements by g$\mathrm{Al}_{2} \mathrm{O}_{3}$ and Pseudomonas fluorescens cells in the presence of desferrioxamine $\mathrm{B}$ : Implication of siderophores for Ce anomaly. Chem. Geol. 212:239-246.

4. Kantar, C., Gillow, J.B., Harper-Arabie, R., Honeyman, B.D., and Francis, A.J. 2005. Determination of stability constants of U(VI)-Fe(III)-citrate complexes. Environ. Sci. Technol. 39: 2161-2168.

5. Ohnuki, T. T. Yoshida, T. Ozaki, M. Samadfam, N. Kozai, K. Yubuta, T. Mitsugashira, T. Kasama, and A.J. Francis. 2005. Interactions of Uranium with Bacteria and Kaolinite Clay. Chem. Geol. 220: 237-243.

6. Ohnuki T., T. Ozaki, T. Yoshida, F. Sakamoto, N. Kozai, E Wakai, A. J. Francis and H. Iefuji. 2005. Mechanisms of uranium mineralization by the yeast Saccharomyces cerevisiae. Geochim. Cosmochim. Acta 69: 5307-5316.

7. Ozaki, T., Y. Suzuki, T. Nankawa, T. Yoshida, T. Ohnuki, T. Kimura, A. J. Francis. Interactions of rare earth elements with bacteria and organic ligands. J Alloys Compds., 408-412: 1334-1338.

8. Nankawa, T., Y. Suzuki, T. Ozaki, T. Ohnuki, and A. J. Francis. Degradation of Eu(III)MalicAcid Complexes by Pseudomonas fluorescens J. Alloys Compds. 408-412, 13291333.

9. Francis A.J. 2006. Microbial transformations of actinides in transuranic- and mixed-wastes: implications for radioactive-waste disposal. In Recent Advances in Actinide Science, pp. 11-19; Eds, I. May, R. Alvares, and N. Bryan. The Royal Society of Chemistry, Cambridge, UK.

10. Francis, A.J. Dodge, C.J., and J.B. Gillow. Biotransformation of plutonium complexed with citric acid. Radiochim. Acta, 94: 731-737. 
11. Ozaki, T., Kimura, T., Ohnuki, T., and Francis. A.J. 2006. Effects of ionic strength on the coordination of $\mathrm{Eu}(\mathrm{III})$ and $\mathrm{Cm}(\mathrm{III})$ to a Gram-negative bacterium, Paracoccus denitrificans. Radiochim. Acta. 94:715-721.

12. Suzuki, Y., Nankawa, T., Yoshida, T., Ozaki, T., Ohnuki, T., Francis, A.J., Tsushima, S., Enokida, Y., and Yamamoto, I. 2006. Redox behavior of uranium in the presence of citric acid. Radiochim. Acta. 94:579-583.

13. Thakur, P.; J.N. Mathur; C.J. Dodge; A.J. Francis; G.R. Choppin. 2006. Thermodynamics and the structural aspects of the ternary complexes of $\mathrm{Am}(\mathrm{III}), \mathrm{Cm}(\mathrm{III})$, and $\mathrm{Eu}(\mathrm{III})$ with Ox and EDTA+Ox. J. Chem. Soc., Dalton Trans. 4829-4837.

14. Mathur, J.N.; P. Thakur; C.J. Dodge; A.J. Francis; G.R. Choppin. 2006. Coordination Modes in the Formation of Ternary Complexes of Am(III), Cm(III) and Eu(III) with EDTA and NTA: TRLFS, ${ }^{13} \mathrm{C}$ NMR, EXAFS, and Thermodynamics of the complexation. Inorg. Chem. 45:8026-8035.

15. Ozaki, T., J.B. Gillow, T. Kimura, T. Ohnuki, Z. Yoshida, A.J. Francis. 2004. Adsorption behavior of $\mathrm{Eu}(\mathrm{III})$ and $\mathrm{Cm}(\mathrm{III})$ on the cell surfaces of microorganisms, Radiochim. Acta. 92: 741-748.

16. Francis, A.J. 2005. Microbial Transformations of Uranium Complexed with Organic Ligands, pp 191-197. In "Uranium in the Environment: Mining Impact and Consequences” Merkel, Broder J., Hasche-Berger, Andrea (Eds.) 2005. Springer Verlag. [Conference Proceedings, 4th International Conference on Uranium Mining and Hydrogeology; Freiberg, Germany, Springer, Berlin].

17. Francis, A.J. 2006. Microbial Transformations of Radio nuclides and Environmental Restoration Through bioremediation. In Proceedings of the DAE_BRNS Symposium on Emerging Trends in Separation Science and Technology SESTEC2006. Eds. P.K. Mohapatra, R.M. Sawant, B. Venkataramani, and V.K. Manchanda. Sept 29- Oct 1, 2006. pp.42-51. Organized by Board of Research in Nuclear Sciences, Department of Atomic Energy

\section{INVITED TALKS}

1. Francis, A.J. "Microbial Transformations of Actinides and Environmental Restoration through bioremeidiation", Harry Reid Center, University of Las Vegas Nevada, February $18,2005$.

2. Francis, A.J. "Microbial Transformation of Radioactive Waste" NYU Graduate School of Journalism Science and Environmental Reporting Program, April 22, 2005.

3. Francis, A.J. "Microbial Transformations of Actinides and Environmental Restoration Through Bioremediation." Special Topic Lecture - ACS sponsored Summer School in Nuclear Chemistry at BNL June 27, 2005.

4. Francis, A.J. Microbial Transformations of Actinides in Transuranic and Mixed Wastes and its Implications on Radioactive Waste Disposal. Paper presented at the Actinides 2005 International conference, July 4- 8, 2005, Manchester, UK.

5. Francis, A.J. Biotransformation of Uranium Associated with Organic Ligands. Paper presented at the Uranium Mining and Hydrogeology VI (UMH IV)International Conference, September 11-14, 2005, Freiberg, Germany. 
6. Francis A.J., C.J. Dodge, and J.B. Gillow. Biotransformation of plutonium complexed with citric acid. Paper presented at the $10^{\text {th }}$ International Conference on Chemistry and Migration Behavior of Actinides and Fission Products in the Geosphere "Migration 2005" September 18-23, 2005, Avignon, France.

7. Francis, A.J. "Microbial Transformations of Radionuclides and Environmental Restoration Through Bioremediation" at the IUPAC sponsored 2nd International Symposium on Green/Sustainable Chemistry, held at the University of Delhi, India. January 10-13, 2006,

8. Francis, A.J. " Microbial Transformations of Radionuclides in Transuranic and Mixed Wastes" at the Indira Gandhi Center for Atomic Research (IGCAR), Kalpakkam, Chennai, Tamil Nadu. January 23-24, 2006.

9. Francis, A.J.; C.J. Dodge; J.B. Gillow. Pu-Futures - The Science 2006 Pacific Grove, California, July 9-13, 2006. Invited talk Microbial Transformations of Plutonium.

10. Francis, A.J. "Microbial Transformations of Actinides and Environmental Restoration Through Bioremediation.” Special Topic Lecture - ACS sponsored Summer School in Nuclear Chemistry at BNL July 17, 2006.

11. Francis, A.J. SESTEC2006. Invited talk entitled "Microbial Transformations of Radionuclides and Environmental Restoration Through Bioremediation" at the SESTEC2006 held at BARC, Mumbai, September 29 - October 1, 2006, organized by the Department of Atomic Energy (DAE) - Board of Research in Nuclear Sciences (BRNS) Biennial Symposium on "Emerging Trends in Separation Science and Technology" SESTEC-2006.

12. Francis, A.J. "“"Emerging Trends in Separation Science and Technology"” September 13 October 14, 2006 at the Indira Gandhi Center for Atomic Research (IGCAR), Kalpakkam, Chennai, Tamil Nadu.

13. Francis, A.J. Microbial Transformations of Radionuclides Released from Nuclear Reprocessing Plants" at the International Symposium on Environmental Modeling and Radioecology" organized by the IES, Rokkasho, Aomori October 18-20, 2006.

14. Francis, A.J. International symposium on Advanced Science Research "Frontiers of Nuclear and Radiochemistry" ASR2006, organized by Advanced Science Research Center (ASRC), Japan Atomic energy Agency (JAEA), Tokai, Ibaraki, Japan. October 26-27, 2006. Inivited talk "Microbial Transformations of Plutonium"

15. Dodge, C.J.; Francis, A.J.; Gillow, J.B. Uranium reduction by Clostridia. Presented at the Annual ERSD PI Meeting, April 5, 2006, DOE, Warrenton, VA.

16. Dodge, C.J. Center for Environmental Molecular Science. Remediation of wastes containing radionuclides and toxic metals using citric acid. Seminar, SUNY-SB, July 15, 2003.

17. Dodge, C.J. Remediation of wastes containing toxic metals and radionuclides using citric acid. CEMS Summer Undergraduate Research Program. June 24, 2005.

18. Nico, P.; Anastasio, C.; Dodge, C.; Fendorf, S.; Francis, A.J.; Hubbard, S.; Shuh, D.; Tomutsa, L.; Tufano, K.; Tyliszczak, T.; Werner, M.; Williams, K. Environmental Science Program at the Advanced Light Source. Presented at the Annual ERSD PI Meeting, April 5, 2006, DOE, Warrenton, VA. 